\title{
IMAGE OF BIRDS IN KHOREZM ART CRAFTS (BASED ON ARCHAEOLOGICAL MATERIALS)
}

\section{Bakhit Gurbanbaevich Turanov}

Associate professor, Candidate of historical sciences, Department of "social and specialty sciences", Regional branch of the Center for professional development under the International Islamic Academy of Uzbekistan in the Republic of Karakalpakstan Nukus, Uzbekistan

Salamat Kudaybergenovich Allambergenov

Assistant Lecturer Department of "methods of teaching history" Nukus State Pedagogical Institute named after Ajiniyoz, Nukus Uzbekistan

\section{ABSTRACT}

The article is devoted to the research of archeological findings of art of khorezm people in ancient and middle-aged period of time the image of birds in the examples of art items. That time in the mythological ideas of khorezm folk art the image of birds was mighty and superficial symbol.

KEYWORDS: - Ancient world, middle aged time, fine art, peacock, pigeon, eagle, pheasant, swan, mythological outlook.

\section{INTRODUCTION}

It is known that the art and artistic craft of each nation is formed on the basis of the worldview and thinking of these ground peoples. Even in the Khorezm Oasis peoples, such as the ancient Eastern countries, animals and birds aks reflection was found in the handicraft items as a product of totemism in ancient times. Mile in the region.avv. The influence of the "wild style" of sak-Scythians in the making of art objects from the middle of the I millennium is evident. In the minds of the peoples of the oasis of that period, the search for a way of life in the image of these creatures came into a strict rule and tradition.

In the wall paintings and artefacts of the monuments of the ancient and antiquity of Khorezm, many of the items made in the images of birds, animals and mythical animals and their depiction are uçraydi. In ancient times, some representatives of the animal and bird world who served as the totem of paganism dinida the doctrine of Zoroastrianism developed in ancient times and in the samples of the material culture of the first Middle Ages with a symbolic divine meaning and meaning.

THE MAIN FINDINGS AND RESULTS 
CURRENT RESEARCH JOURNAL OF HISTORY 2(7): 21-25, July 2021

DOI: https://doi.org/10.37547/history-crjh-02-07-05

ISSN 2767-472X

(C)2021 Master Journals

\section{Crossref dof 80 Google}

Accepted 15th July, 2021 \& Published 20th July, 2021

In Zoroastrianism, birds were recognized as divinely powerful beings, and some were considered symbols of the gods in the minds of the local people. According to the Avesta, the sacred book of Zoroastrianism, Humo is a bird of divine power with happiness and wealth. He was invisible to anyone, and it was believed that if his shadow fell on a man, he would be very happy and rich. The image of sausage in the arts and crafts of the peoples of Central Asia dates back to the IV century.

In the minds of the peoples of the ancient and early medieval Khorezm oasis, in addition to humus, birds such as peacocks, white birds, pigeons, roosters were recognized as symbols of divinity. Inostrantsev noted that in the preIslamic religious and mythological thinking and worldview of the peoples of the Khorezm oasis, birds expressed the soul or its spirit, which was separated from the human body. Yu.A., an expert on the history of the ancient religions of the peoples of the oasis. Developing this idea, Rapoport admits that "birds are not only the symbol of the human soul, but also the white bird and the peacock as a symbol of the goddess Anaxita" [5, -P.94].

In the pre-Islamic period, the image of birds such as humo, peacock, pigeon, white bird, and rooster had a divine meaning in the thinking and artistic handicrafts of the peoples of the oasis. Typically, some representatives of the bird world are depicted in art objects as images of gods.

This is evidenced by the images of birds depicted on the thresholds of ancient and ancient Khorezm monuments [5, -P.93.-Fig.47-50]. In the monuments of Mizdakhon and Qubatag, some ostodons have the image of birds.

As a celestial bird, the eagle is represented in the art of the peoples of the East as a symbol of the sun and in folk epics as a creature possessing power and authority. The ruler's crown on the murals of Khorezm's Akshakhan Fortress (5th- 4th centuries $\mathrm{BC}$ ) is in the form of a bird, the ruler of Qoyqrilganqala (4th-3rd centuries BC) is depicted as a ruler wearing a large helmet in the form of a legendary bird. a sculptural statue wearing a ruler's crown in the form of a white eagle was found on his head [7, -P.27, 88].

The images of the crown of the ruler Vaziramir on Khorezm coins (2nd half of the 3rd century and the beginning of the 4th century) and the crown of the ruler on the melodic III century copper coins found in Angola are reflected in the form of an eagle [7, -P.27,88]. Images of a ruling crown in the form of an eagle are also found on Parthian and Kushan coins. Undoubtedly, the image of birds on coins and murals represented the image of a divine ruler.

It is known that with the spread of Islam, due to religious prohibitions, the nature of the decoration of objects in architecture and artistic crafts, the forms and stylistic features of fine arts also changed. In Islam, the doctrine of kalam, which has a negative attitude to the depiction of living beings, was formed in the late eighth and early ninth centuries. Nevertheless, pre-Islamic emblems, plots, and themes continued to be reflected in many ceramics, bronze, wood, and glass ornaments of applied art.

At the beginning of the IX-XIII centuries, the peoples of the Khorezm oasis were not yet complete in the decoration of artifacts, but under the influence of Islam we can see a gradual increase in Islamic-handicraft and handicraft patterns. The artistic style of expressing the image of birds also changes radically, i.e. it is reflected in a stylized way. Although the image of birds takes on a more abstract form and merges with Islamic patterns, it still continues as an integral part of the traditional style. Appearances of art objects, including jewelry, were in the form of bracelets made of bird, animal, fish, mythical creature, two ends resembling the head of a snake. In addition to jewelry, the image of birds 
CURRENT RESEARCH JOURNAL OF HISTORY 2(7): 21-25, July 2021

DOI: https://doi.org/10.37547/history-crjh-02-07-05

ISSN 2767-472X

(C)2021 Master Journals

\section{Crossref dof 80 Google}

Accepted 15 th July, 2021 \& Published 20thJuly, 2021

is also common on glazed pottery.

Early medieval pottery depicts birds such as pigeons, pheasants, and eagles.

In the cultural layers of the Kardar fortress of the IX-X centuries were found a mysterious ceramic bowl with a generalized image of an eagle, a snake and a fish [3, -P.105-109.]. The diameter of the bottom of the bowl is $13 \mathrm{~cm}$, the diameter of the preserved upper part is $22-24 \mathrm{~cm}$. The eagle, reflected in the inside of the bowl, held the snake tightly to its body with its claws on both feet, with flower petals dropped in three places on the snake. Both wings of the eagle have an image of a fish on the outside.

In the mythological imagination of the peoples of Central Asia, the eagle was considered the ruler of the sky, the prophetic sunbird. Birds in general, including the eagle, are a symbol of the human soul. Legend has it that the eagle is a bird that takes the soul of a dead person to heaven.

Another mysterious ceramic vessel of the IX-X centuries in the Kardar monument depicts a pheasant and a dove [3, -P.105-109]. Similar pottery with the image of a pheasant and a dove is common in medieval monuments in Central Asia, such as Merv, Termez, Fergana, Shosh.

The peoples of Central Asia are represented in folklore, heroic epics as peacocks and pheasants as symbols of light, kindness and auspicious day.

In the XII-XIV centuries there are many images of "sitting" or "flying" duck, "peacock", "peacock's eye". Such images are reflected in glazed pottery. They are recorded from such monuments of Khorezm as Old-Urgench, Qizilqala, Mizdakhon, Qavatkala. The emergence of this image is associated with the religious outlook and artistic traditions of the ancient Khorezm peoples. According to the concepts in Zoroastrianism, the peacock and the dove are the birds that walk with the goddess Anaxita. Typically, their images are reflected in the image of birds walking around the goddesses.

Yu.A. According to the report, in the religious worldview of the ancient Khorezm peoples, the peacock was understood as a symbol of the goddess Anaxita. The seal found in the first medieval monument of Yakkaparson (VIII century) has an image of a peacock on its beak, possibly carrying a crown [4, -P.14. -Fig.7]. According to experts, these images reached the samples of material culture of the Volga (Palace), North Caucasus (Madjar), Moldova (Old Orhei), Russian (Great Novgorod) as a result of the influence of Khorezmian masters after the Mongol invasion [2, -B.128]. In the XIII-XIV centuries, these territories, like Khorezm, were under the control of the Golden Horde. The similarity of the pottery forms (bowls, bowls) and even the images and patterns (duck, peacock, peacock's eye) found in Khorezm and Eurasia at that time show that the Khorezmians had strong cultural and economic ties with the local peoples. [8, -B.33-37].

In the finds of the oasis monuments, the image of birds is also found in artistic metal objects. One of them depicts a white bird spreading its wings in a bronze mirror recorded from Mizdakhon mahallas of XIII-XIV centuries [6, -Mizdakhon. Kp 391. inv 8951/19]. The perimeter of the white bird is decorated with plant motifs. The image of a white bird in the mirror is probably a pair. Because white birds live in pairs by nature. In the imagination of the peoples of Central Asia, white birds are represented as a symbol of happiness, wealth, purity and love from ancient times to the present day.

The bronze ring of the belt, found in the cultural layers of the city of Khiva in the XII century, depicts a relief image of two opposite birds, surrounded by Arabic inscriptions [7, -P.50]. During this period, the depiction of Arabic inscriptions in Kufu calligraphy was reflected in artistic ornaments as a new style. 
CURRENT RESEARCH JOURNAL OF HISTORY 2(7): 21-25, July 2021

DOI: https://doi.org/10.37547/history-crjh-02-07-05

ISSN 2767-472X

(C)2021 Master Journals

\section{Crossref dof 80 Google}

Accepted 15 ${ }^{\text {th }}$ July, 2021 \& Published 20thJuly, 2021

Artistic handicrafts not only depict birds, but also some handles and lids are made in the form of birds. A bird-shaped ornament was placed on the handle of a bronze vessel found in the 12th century layers of the Jigarband monument in South Khorezm [1, -B. 87. Figure 35/11]. The ornament is in the form of a cuckoo bird, with a split tail and a lowered eye at the points of relief. The height of the ornament is $3.5 \mathrm{~cm}$, the surface is flat, the lower part is square.

In Central Asia in the XI-XIII centuries it was common to put bird-shaped ornaments on handles and other pieces of artistic metal objects. In particular, it has become a tradition to decorate bronze lanterns in the form of birds.

Zamakhshar in the monuments of Khorezm in the X-XI centuries, the Red Fortress in the XII-XIII centuries [6, - Red Fortress. Many ornaments in the form of bird statues have been found. Kp. 3602. inv. 239]. They are made of cast bronze. Of the three ornaments on the Zamakhshar monument, two resemble a duck and one resembles a dove. The bird statue at the Red Castle monument is in the shape of a dove, with its wings and tail depicted in a relief line. The bird-shaped ornament is hollow, $5.3 \mathrm{~cm}$ high and $5.5 \mathrm{~cm}$ long.

Similar bronze and ceramic statues have been recorded in the Shekhr-Islam and Palace Berka monuments of southern Turkmenistan in the 13 th and 14 th centuries.

In the late medieval crafts of Khorezm, the creation of artistic ornaments in the form of birds and the depiction of birds continued as a traditional style. Especially in the jewelry craft, it is common to make earrings in the shape of a bird or a bird in the shape of a bird. The ornament of the glittering "Bird's Nest" had a symbolic meaning. In the center and on both sides of the jewelry history, a replica of a threetoothed claw is made of tubes with feathers attached, and between the claws are placed rings with a pair of bird images inside as a symbol of the couple [7, -P.88-89].

In the mythological imagination, folklore and applied arts of the inhabitants of the Khorezm oasis and the surrounding nomadic peoples, birds have been represented as a symbol of glory and divinity from ancient times to the end of the Middle Ages.

According to Abulgazi Bahodirkhan's "Shajarayi tarokima", in the time of Oguzkhan, the falcon, eagle, owl, hawk, turunboy, falcon, humoy, tuyun, crow were considered sacred birds - totem [7, P.88]. Orientalist scholar V.V. Based on the information of Barthold Rashididdin, he writes that totemism was preserved in the Oguzs even in the Islamic period and that they respected every bird, considered it a member of the seed, did not touch them and did not eat their meat. In addition, the emergence of ethnonymous seeds in the Uzbek language, such as eagle, eagle, is also associated with totemistic views.

\section{Conclusion}

Thus, birds such as humo, peacock, eagle, pigeon, white bird, swallow, which are a symbol of glory and divinity in the mythological thinking of the peoples of the oasis, had a symbolic meaning in folk art until the beginning of the twentieth century. This was a sufficient basis for artisans to reflect the image and appearance of these birds on ancient and medieval art objects.

\section{REFERENCES}

1. Vishnevskaya N.Yu. Remeslennye izdeliya Djigerbenta. -M .: 2001.

2. Grajdankina N.S., Rtveladze E.V. Influence of Khorezm on ceramic production zolotoordynskogo city of Madjara // SA. 1971. - № 1. 
CURRENT RESEARCH JOURNAL OF HISTORY 2(7): 21-25, July 2021

DOI: https://doi.org/10.37547/history-crjh-02-07-05

ISSN 2767-472X

(C)2021 Master Journals

Crossref dof 81 Google

Accepted 15 ${ }^{\text {th }}$ July, 2021 \& Published 20thJuly, 2021

3. Mambetullaev M.M., Turmanov J.T., Yusupov O.J. Polyvnaya ceramics Kerdera // Vestnik KKO AN RUz. 2006. - № 1-2. - S. 105-109.

4. Nerazik E.E. Raskopki Yakka-Parsana // MXE. - M .: AN USSR, 1963. Vyp.7. - S. 3-38.

5. Rapoport Yu.A. Iz istorii relegii drevnego Xorezma // TXAEE. T.VI.-M .: 1971.

6. Museum of Art of the Republic of Karakalpakstan. Red Castle. Kp. 3602. inv. 239

7. Faxretdinova D.A. Jewelry art of Uzbekistan.Tashkent, Gafura-Gulyama. 1988.

8. Yakubovskiy A.Yu. K voprosu o proisxojdenii remeslennoy promыshlennosti Saraya Berke // GAIMK. - L., 1931. T. 8. Vyp. 2-3. - S. 1-48. 